\title{
Career Choice Regret During COVID-19 Among Healthcare Students and Professionals in Mainland China: A Cross-Sectional Study
}

\section{Guoyi Yang}

Peking University People's Hospital

\section{Ling Wang}

Peking University People's Hospital

Jia Wang

Peking University People's Hospital

\section{Zixian Geng}

Peking University People's Hospital

\section{Huixin Liu}

Peking University People's Hospital

\section{Tao Xu ( $\nabla$ xutao@pkuph.edu.cn )}

Peking University People's Hospital

\section{Research Article}

Keywords: COVID-19, career choice regret, healthcare professionals, medical students, psychological resilience, professional value

Posted Date: February 1st, 2021

DOl: https://doi.org/10.21203/rs.3.rs-151453/v1

License: (9) This work is licensed under a Creative Commons Attribution 4.0 International License. Read Full License 


\section{Abstract}

\section{Background}

The COVID-19 epidemic affected the career choice of healthcare professionals and students. To explore career choice regret of healthcare professionals and students during COVID-19 outbreak and its affected factors.

\section{Methods}

Convenience sample of nurses, doctors, and medical students were recruited from hospitals and universities nationwide. The data collected including demographic information, professional value before and after the COVID-19 outbreak, the Connor-Davidson Resilience Scale, and career choice regret level by an online questionnaire. Multinominal logistic regression was employed to explore the factors associated with career choice regret.

\section{Results}

In total, 9322 participants of convenience sampling were enrolled in, including 5786 nurses, 1664 doctors, and 1872 medical students. $6.7 \%$ participants had career choice regret. Multinominal logistic regression analysis showed, compared to participants with no regret, that as levels of resilience increased, the odds of experiencing career choice regret decreased $(\mathrm{OR}=0.951, \mathrm{P} \otimes 0.001)$, while participants with lower professional value evaluation after the COVID-19 outbreak had higher probability to experience career choice regret(OR=1.552,P囚0.001). Medical students were more likely to regret than nurses $(\mathrm{OR}=1.654, \mathrm{P}=0.002)$, participants whose career/major choice was according to their personal ideal had higher risk of experience career choice regret $(\mathrm{OR}=1.592, \mathrm{P} \otimes 0.001)$, while participants who were very afraid of the coronavirus had higher risk to experience career choice regret then participants with no fear at all(OR=1.997, $\mathrm{P}=0.004)$.

As for the medical students, results indicated that medical students major in nursing and undergraduates had higher risk to experience career choice regret compared to medical students major in clinical medicine and postgraduate (Master or PhD), with an odds ratios of 2.645 and 6.851 respectively.

\section{Conclusions}

A minority of healthcare professionals and medical students regretted their career choices during the COVID-19 outbreak. Enhance personal psychological resilience and professional value would helpful to reduce career choice regret among healthcare professionals and students during pandemic.

\section{Background}

The coronavirus disease 2019(COVID-19) is a severe acute respiratory infection caused by SARS-CoV-2 which is high transmission. it has spread to 200 countries and has been declared a global pandemic by 
the World Health Organization (WHO). Globally, as of 24 November 2020, there have been more than 58 million confirmed cases of COVID-19, including 1385 thousand deaths, reported to WHO(1). With the rapid and extensive spread, doctors and nurses have been confronted with mounting challenges that they have not been faced before.

They encounter work difficulties due to lack of resources and threats to the safety of their loved ones(2) and the highest risk of being infected(3). Moreover, the COVID-19 epidemic had negative impacts on the psychology of healthcare professionals. Studies have showed during the COVID-19 outbreak, healthcare professionals dealing with COVID-19 were under increased levels of anxiety, depression, and stress $(4,5)$. The epidemic also has increased medical students' perceptual awareness of the high-risk characteristics of medical and health services(6).

Previous studies showed that depressive symptoms and higher levels of burnout were related to decrease medical career interest, increased career choice regret(7-9). CNN News reported that affected by the epidemic, some American nurses were overwhelmed to strike(10).

To depict the situation of career choice regret among healthcare professionals and students during COVID-19 pandemic and to explore strategies to prevent career choice regret among healthcare professionals and students, we conducted the following study.

\section{Methods}

\subsection{Study design, setting, and participants}

A cross-sectional study was conducted from April 23 to May 20,2020. Convenient sampling of healthcare professionals (doctors and nurses) and medical students in mainland China were recruited nationwide online. All participants were invited to complete the questionnaire online via Questionnaire Star (https://www.wjx.cn).

\subsection{Measurements}

The online questionnaire collected the following information, general information, professional value before and after the outbreak of COVID-19, the Connor-Davidson Resilience scale and one question about career choice regret affected by the COVID-19. A pilot study was conducted before the survey to make sure all the questions/items were clear and unambiguous. Details of each part are as described below.

\section{General information}

The following information were collected from all the participants, including gender, age, educational level, the reason of career choice for healthcare professionals/ major choice for medical students, whether have experienced verbal violence or physical violence during medical practicing, the willingness to participate in treatment or nursing during public health emergencies and the degree of fear of the coronavirus. In addition to the above, doctors and nurses were also asked if they participated in the 
treatment or nursing of patients with COVID-19, and medical students were asked whether their current major was the first choice, whether have had started internship in the hospital .

\section{Professional value before and after the COVID-19 outbreak}

This part contains 5 items to investigate the professional value of the participants before and after the outbreak of COVID-19. Each item using a 5- Likert response scale, response options ranged from "nonconformity" to "full conformity" (score brange,5-25) and a higher score indicated lower professional value evaluation.

\section{The Connor-Davidson Resilience scale (CD-RISC)}

The scale was developed by Connor and Davidson(11) and was revised by $\mathrm{Yu}(12)$, comprises 3 dimensions (competency, toughness, and adaptability), 25 items rated on a 5-point scale (0-4), with higher scores reflecting greater resilience. The internal consistency coefficient of the questionnaire is 0.89 , which has good reliability and validity.

\section{Career choice regret}

This part contains one question for all the participants " after the outbreak of COVID-19, I regret the choice I made about my career". Response options were "strongly agree", "agree" ,"neutral”, "disagree" and"strongly disagree"; responses of "strongly agree" or "agree" indicated with career choice regret, "disagree" and"strongly disagree" indicated without career choice regret.

\subsection{Statistical analysis}

Categorical data are presented as frequencies and percent, continuous data are described by mean and standard deviation or median and interquartile range (IQR) as appropriate. Mann-Whitney U or KruskalWallis $\mathrm{H}$ test were performed to test the association of career choice regret with the following categorical variables, identity, gender, whether experienced physical violence during practicing, whether experienced verbal violence during practicing, the reason of career/major choice, major, work intention after graduation, whether current major was the first choice, whether have had started internship in the hospital, whether participated in the treatment or nursing of patients with COVID-19. Test for Linear Trend was used to test the association of career choice regret with the fear level after the COVID-19 outbreak. Paired $t$ test or Wilcoxon signed-rank test were used to measure the change of professional value during COVID-19. Multinomial logistic regression analysis was performed to identify factors associated with regret of choice of career among all the participants, a subgroup analysis was also done among potential healthcare professionals (medical students). All statistical analyses were conducted in SPSS version 26.0 (IBM, Chicago, IL, USA), and $p<0.05$ was considered to be statistically significant.

\subsection{Ethics statement}


This study was approved by Peking University People's Hospital Ethical Committee [No:2020PHB181-01]. The online survey was anonymous. Informed consent was obtained from all subjects(age $\geq 18$ ), if subjects are under 18, from a parent and/or legal guardian when they accessed the online survey. All methods were carried out in accordance with relevant guidelines and regulations.

\subsection{Patient and Public Involvement}

Patients or the public were not involved in the design, or conduct, or reporting, or dissemination plans of our research.

\section{Results}

\subsection{Participants' characteristics}

A total of 9322 participants were finally included, consisted of 5786 nurses, 1664 doctors, and 1872 medical students. Among the medical students, 1100 are major in clinical medicine and 772 are major in nursing. Among the healthcare professionals, 2482 were involved in the treatment or nursing the patient with COVID-19, accounting for $33.3 \%$. The average age of participants was 31.65 years; 1796 were male (19.3\%) and 7526 were female $(80.7 \%$, Table 1$)$.

\subsection{The level of career choice regret among healthcare professionals and potential healthcare professionals}

There were 5506 of 9322 respondents (59.1\%) reported that they had no regret of their choice of career, while 624 of 9322 respondents $(6.7 \%)$ reported that they had career choice regret. For the question about whether the outbreak of covid-19 made them regret the choice they made about their career, $4.5 \%$ reported "agree" and $2.5 \%$ reported "strongly agree" among healthcare professionals, while for medical students, $3.9 \%$ and $1.4 \%$ reported "agree" and "strongly agree".

\subsection{Factors associated with career choice regret after the COVID-19 outbreak}

The healthcare professionals who participated in the treatment or nursing of patients with COVID-19 have lower career choice regret after the COVID-19 outbreak $(Z=-2.726, P=0.006)$.For all the participants, in the univariate analysis (Table 2), career choice regret after the COVID-19 outbreak was associated with identity, gender, having experienced physical or verbal violence, the reason of career/major choice was personal ideal or family will.

As for medical students, univariate analysis results showed that, career choice regret after the COVID-19 outbreak was associated with their current major, work intention after graduation, whether their current major was the first choice, whether have had started internship in the hospital, willingness to participate in treatment or nursing facing public health emergencies. (Table 3).

\subsection{Factors associated with career choice regret after the COVID-19 outbreak}


Multinominal logistic regression results(Table 4) showed that as levels of resilience increased, the odds of experiencing career choice regret decreased $(O R=0.951, P<0.001=$, while participants with higher professional score (means lower professional value evaluation) had higher probability to experience career choice regret

$(\mathrm{OR}=1.552, \mathrm{P}<0.001=$. Medical students were more likely to regret about their career choice than nurses $(O R=1.654, P=0.002)$, participants whose career/major choice was according to their personal ideal had higher risk of experience career choice regret $(O R=1.592, P<0.001 \rrbracket$, participants who have not experienced physical violent medical incidents had lower probability to experience career choice regret $(\mathrm{OR}=0.673, \mathrm{P}=0.001)$, while participants who were very afraid of the coronavirus had higher risk to experience career choice regret then participants with no fear at all $(\mathrm{OR}=1.997, \mathrm{P}=0.004)$.

As for the medical students, multinominal logistic regression analysis results (Table5) indicated that medical students major in nursing and undergraduates had higher risk to experience career choice regret compared to medical students major in clinical medicine and postgraduate (Master or PhD), with an odds ratios of 2.645 and 6.851 respectively.

\section{Discussion}

This nationwide research investigated the current situation and influencing factors of the career choice regret of healthcare professionals and medical students during the COVID-19 epidemic. Although the epidemic has brought challenges to healthcare, but our research showed only $6.7 \%$ healthcare professionals and medical students regret about their career choice. This situation is similarly to previous pandemic(13).Despite the initial shock, the health professionals in China appear to exhibit high levels of commitment and professionalism. The increasing knowledge about preventing and dealing with the disease, and the development of more specific procedural and treatment protocols, alongside educational activities, contributed to improving the morale of healthcare workers dealing with the pandemic.

Our research shows that the degree of regret of medical students' career choice is lower than that of medical staff, and it is statistically significant. Among medical students, those who have had started internship have more risk to experience career choice regret than those who have not entered clinical internship. It is possible that the COVID-19 pandemic resulted in cancellation of medical student clinical rotations(14).Therefore, educators should intervene and cultivate their professional values after students started intership, and targeted efforts by medical schools to address these concerns through enhanced virtual curriculum development and advising strategies will become increasingly important. So as to reduce their professional regret and reserve talents for the medical career.

The multivariate analysis showed that the professional value was the influence factor of career choice regret during the COVID-19 outbreak. The population with higher professional value showed lower level of regret. Although the professional value has declined slightly after the epidemic, it was still at a high level, and the impact on professional regret was still positive. Many previous studies have shown that personal achievement leading doctors to strongly recommend their work in the health center to dear ones but not 
to put aside other job options(15). Therefore, cultivating the professional value of medical staff in peacetime was more conducive to reducing the impact on the career choices of medical staff after major public health incidents.

When the COVID-19 outbreak, healthcare professionals directly participated in the treatment or nursing of the patient with COVID-19. They were facing great mental and physical pressure. Regarding the psychological suffering of individuals, an important key psycho-social factor was psychological resilience. Our research showed that the stronger a person's psychological resilience was, the lower his regret for career choices when facing the COVID-19 epidemic. Resilience plays a decisive role in the response of individuals under pressure and can help them deal with difficulties and adverse circumstances more effectively(16). The previous study showed psychosocial strengths play a significant role in subsiding the risk associated with severity of disease when facing COVID-19(17). Therefore, it is believed that higher levels of resilience can protect a person from pressure and reduce the risk of regretting career choices.

\section{Conclusion}

During COVID-19 outbreak in China, career choices of medical staff and medical students was low. Career intention is personal ideal, experienced physical or verbal violence, higher psychological resilience, higher professional value after the epidemic, lower change of professional value were associated with a lower career choice regret. Medical students' career choice regret was lower than the health professionals. For the medical students, having entered the clinical practice stage, major was not the first choice for college entrance examination volunteers, work intention after graduation wasn't hospital had higher level of regret.

\section{Limitations Of This Study}

Our study is limited in several ways. First, as a cross-sectional design, this study could only evaluate the career choice regret at the time without the longitudinal observation of the subjects, so follow up is warranted in the future. Second, the survey use convenience sample recruited online, which could resulted in selection bias. However, the findings of this study may have some generalizability given the large sample.

\section{Declarations}

\section{Ethics approval and consent to participate}

This study was approved by Peking University People's Hospital Ethical Committee [No:2020PHB181-01]. The online survey was anonymous. Informed consent was obtained from all subjects(age $\geq 18$ ), if subjects are under 18, from a parent and/or legal guardian when they accessed the online survey. All methods were carried out in accordance with relevant guidelines and regulations. 


\section{Consent for publication}

Not applicable

\section{Availability of data and materials}

The datasets used and/or analysed during the current study are available from the corresponding author on reasonable request.

\section{Competing interests}

The authors declare that they have no competing interests

\section{Funding}

There is no funding support for this research

\section{Authors' contributions}

(I) Conception and design: All authors

(II) Administrative support: HXL, TX

(III) Provision of study materials or patients: All authors

(IV) Collection and assembly of data: GYY, HXL, JW, ZXG

(V) Data analyses and interpretation: GYY, HXL, LW, TX

(VI) Preparation of the manuscript: All authors

(VII) Final approval of manuscript: All authors

\section{Acknowledgements}

We thank the health professionals and medical students who participated in this survey and thank the hospital and university providing us.

\section{References}

1. Coronavirus disease (COVID-19) https://www.who.int/emergencies/diseases/novel-coronavirus2019.

2. Robblee J, Buse DC, Halker Singh RB, Schusse CM, Riggins N, Rayhill ML, et al. Eleven things not to say to healthcare professionals during the COVID-19 pandemic. Headache. 2020. 
3. Ağalar C, Öztürk Engin D. Protective measures for COVID-19 for healthcare providers and laboratory personnel. TURK J MED SCI. 2020;50(Si-1):578-84.

4. Tsamakis K, Rizos E, Manolis AJ, Chaidou S, Kympouropoulos S, Spartalis E, et al. COVID-19 pandemic and its impact on mental health of healthcare professionals. EXP THER MED. 2020;19(6):3451-3.

5. Kang L, Ma S, Chen M, Yang J, Wang Y, Li R, et al. Impact on mental health and perceptions of psychological care among medical and nursing staff in Wuhan during the 2019 novel coronavirus disease outbreak: A cross-sectional study. BRAIN BEHAV IMMUN. 2020;87:11-7.

6. Ikhlaq A, Bint ERH, Bashir I, ljaz F. Awareness and Attitude of Undergraduate Medical Students towards 2019-novel Corona virus. Pak J Med Sci. 2020;36(Covid19-s4):S32-s6.

7. Hu L, Wu H, Zhou W, Shen J, Qiu W, Zhang R, et al. Positive impact of COVID-19 on career choice in pediatric medical students: a longitudinal study. TRANSL PEDIATR. 2020;9(3):243-52.

8. Tian L, Pu J, Liu Y, Zhong X, Gui S, Song X, et al. Relationship between burnout and career choice regret among Chinese neurology postgraduates. BMC MED EDUC. 2019;19(1):162.

9. Grace MK. Depressive symptoms, burnout, and declining medical career interest among undergraduate pre-medical students. INT J MED EDUC. 2018;9:302-8.

10. Paul P. Murphy, Young R, Carpenter J. Detroit hospital nurses refuse to work without more help, ordered to leave: Cable News Network; 2020 [updated April 8, 2020. Available from: https://edition.cnn.com/2020/04/07/us/detroit-nurses-sinai-grace-coronavirus/index.html.

11. Connor KM, Davidson JR. Development of a new resilience scale: the Connor-Davidson Resilience Scale (CD-RISC). DEPRESS ANXIETY. 2003;18(2):76-82.

12. Yu XN, Lau JT, Mak WW, Zhang J, Lui WW, Zhang J. Factor structure and psychometric properties of the Connor-Davidson Resilience Scale among Chinese adolescents. COMPR PSYCHIAT. 2011;52(2):218-24.

13. Cowden J, Crane L, Lezotte D, Glover J, Nyquist AC. Pre-pandemic planning survey of healthcare workers at a tertiary care children's hospital: ethical and workforce issues. INFLUENZA OTHER RESP. 2010;4(4):213-22.

14. Byrnes YM, Civantos AM, Go BC, McWilliams TL, Rajasekaran K. Effect of the COVID-19 pandemic on medical student career perceptions: a national survey study. MED EDUC ONLINE. 2020;25(1):1798088.

15. Santana S, Loureiro SMC. Analysing drivers and outcomes of job and professional satisfaction at health centres in Portugal. Benchmarking. 2019;26(4):1357-75.

16. Windle G. What is resilience? A review and concept analysis. Reviews in Clinical Gerontology. 2011;21:152-69.

17. Saleem M, Dastgeer S, Durrani AK, Saad AA, Manzoor Z, Hussain HN. Self-control Mediates the Relationship between Psychosocial Strengths and Perceived Severity of COVID-19 among Frontline Healthcare Professionals of Pakistan: A Single Center Experience. Pak J Med Sci. 2020;36(Covid19s4):S62-s6. 


\section{Tables}

Table 1 Personal and professional characteristics of participants $(n=9322)$ 


\begin{tabular}{|c|c|c|c|c|}
\hline \multirow[b]{2}{*}{ Characteristics } & \multicolumn{2}{|c|}{ healthcare professionals } & \multicolumn{2}{|l|}{ medical students } \\
\hline & nurses & doctors & Clinical Medicine & nursing \\
\hline \multicolumn{5}{|l|}{ Gender } \\
\hline Male & 192(3.3\%) & $1018(61.2 \%)$ & $468(42.5 \%)$ & $118(15.3 \%)$ \\
\hline Female & $5594(96.7 \%)$ & $646(38.8 \%)$ & $632(57.5 \%)$ & $654(84.7 \%)$ \\
\hline Age & $33.02 \pm 7.42$ & $38.65 \pm 8.27$ & $21.60 \pm 3.02$ & $20.60 \pm 2.81$ \\
\hline \multicolumn{5}{|l|}{ Educational level } \\
\hline Below Bachelor degree & 1907(33.0\%) & $60(3.6 \%)$ & 0 & $135(17.5 \%)$ \\
\hline Bachelor degree & $3765(65.1 \%)$ & $773(46.5 \%)$ & $897(81.5 \%)$ & $598(77.5 \%)$ \\
\hline Master's degree & $114(2.0 \%)$ & $506(30.4 \%)$ & $149(13.5 \%)$ & $37(4.8 \%)$ \\
\hline Doctorate & 0.0 & $325(19.5 \%)$ & $54(4.9 \%)$ & $2(0.3 \%)$ \\
\hline \multicolumn{5}{|c|}{ Work intention after graduation } \\
\hline Tertiary hospital & $\mathrm{N} / \mathrm{A}$ & N/A & $972(88.4 \%)$ & $642(83.2 \%)$ \\
\hline Primary hospital & $\mathrm{N} / \mathrm{A}$ & $\mathrm{N} / \mathrm{A}$ & $69(6.3 \%)$ & $43(5.6 \%)$ \\
\hline Others & $\mathrm{N} / \mathrm{A}$ & $\mathrm{N} / \mathrm{A}$ & $59(5.4 \%)$ & $87(11.3 \%)$ \\
\hline \multicolumn{5}{|c|}{ Whether current major is the first choice } \\
\hline Yes & $\mathrm{N} / \mathrm{A}$ & $\mathrm{N} / \mathrm{A}$ & $1025(93.2 \%)$ & $456(59.1 \%)$ \\
\hline No & $\mathrm{N} / \mathrm{A}$ & $\mathrm{N} / \mathrm{A}$ & $75(6.8 \%)$ & $316(40.9 \%)$ \\
\hline \multicolumn{5}{|c|}{ Whether have had started internship in the hospital } \\
\hline Yes & $\mathrm{N} / \mathrm{A}$ & N/A & $318(28.9 \%)$ & $431(55.8 \%)$ \\
\hline No & $\mathrm{N} / \mathrm{A}$ & $\mathrm{N} / \mathrm{A}$ & 782(71.7\%) & $341(44.2 \%)$ \\
\hline \multicolumn{5}{|c|}{ Reason of major/career choice } \\
\hline \multicolumn{5}{|l|}{ Personal ideal } \\
\hline Yes & $996(59.9 \%)$ & $2048(35.4 \%)$ & $825(75.0 \%)$ & $396(51.3 \%)$ \\
\hline No & $668(40.1 \%)$ & $3738(64.6 \%)$ & $275(25.0 \%)$ & $376(48.7 \%)$ \\
\hline \multicolumn{5}{|l|}{ Family wishes } \\
\hline Yes & $826(49.6 \%)$ & $2824(48.8 \%)$ & $567(51.5 \%)$ & $358(46.4 \%)$ \\
\hline
\end{tabular}


Table 2 Univariate analysis of influencing factors of career choice regret after COVID-19 outbreak $(n=9322)$

Variable I regret the career choice I made strongly disagree neutral agree strongly $P^{*}$ disagree agree

Identity

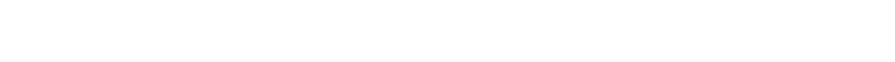

$\begin{array}{llllll}\text { Doctor } & 277 & 720 & 542 & 79 & 46 \\ \text { Nurse } & 1075 & 2240 & 2071 & 259 & 141 \\ \text { Student } & 391 & 803 & 579 & 73 & 26\end{array}$

Gender

Male

Female

353

76

1390

764

543

2999

2649

$\begin{array}{ll}92 & 44 \\ 319 & 169\end{array}$

Whether experienced physical violence

\begin{tabular}{|lllllr} 
Yes & 282 & 622 & 592 & 125 & 72 \\
No & 1461 & 3141 & 2600 & 286 & 141
\end{tabular}

Whether experienced verbal violence

$$
\text { e }
$$




\begin{tabular}{|llllll|} 
General fear & 607 & 1842 & 1687 & 194 & 85 \\
\hline No fear & 518 & 1125 & 708 & 82 & 34 \\
\hline No fear at all & 365 & 299 & 191 & 24 & 25 \\
\hline
\end{tabular}

Note:*P for trend. 
Table 3 factors of associated career choice regret after COVID-19 outbreak among medical students $(n=1872)$

Variable I regret the career choice I made

strongly disagree disagree neutral agree $\begin{aligned} & \text { strongly } \\ & \text { agree }\end{aligned} \mathrm{P}^{*}$

Educational level

0.001

\begin{tabular}{llllll} 
Below Bachelor degree & 39 & 47 & 43 & 4 & 2 \\
\hline Bachelor degree & 326 & 649 & 457 & 44 & 19 \\
\hline Above Bachelor degree & 26 & 107 & 79 & 25 & 5 \\
\hline Major & & & & & \\
\hline Nursing & 101 & 306 & 310 & 39 & 16 \\
\hline Clinical medicine & 101 & 306 & 310 & 39 & 16
\end{tabular}

Work intention after graduation

0.001

$\begin{array}{llllll}\text { Tertiary hospital } & 349 & 716 & 482 & 48 & 19 \\ \text { Primary hospital } & 24 & 47 & 32 & 8 & 1 \\ \text { Others } & 18 & 40 & 65 & 17 & 6\end{array}$

Whether major is the first choice

0.001

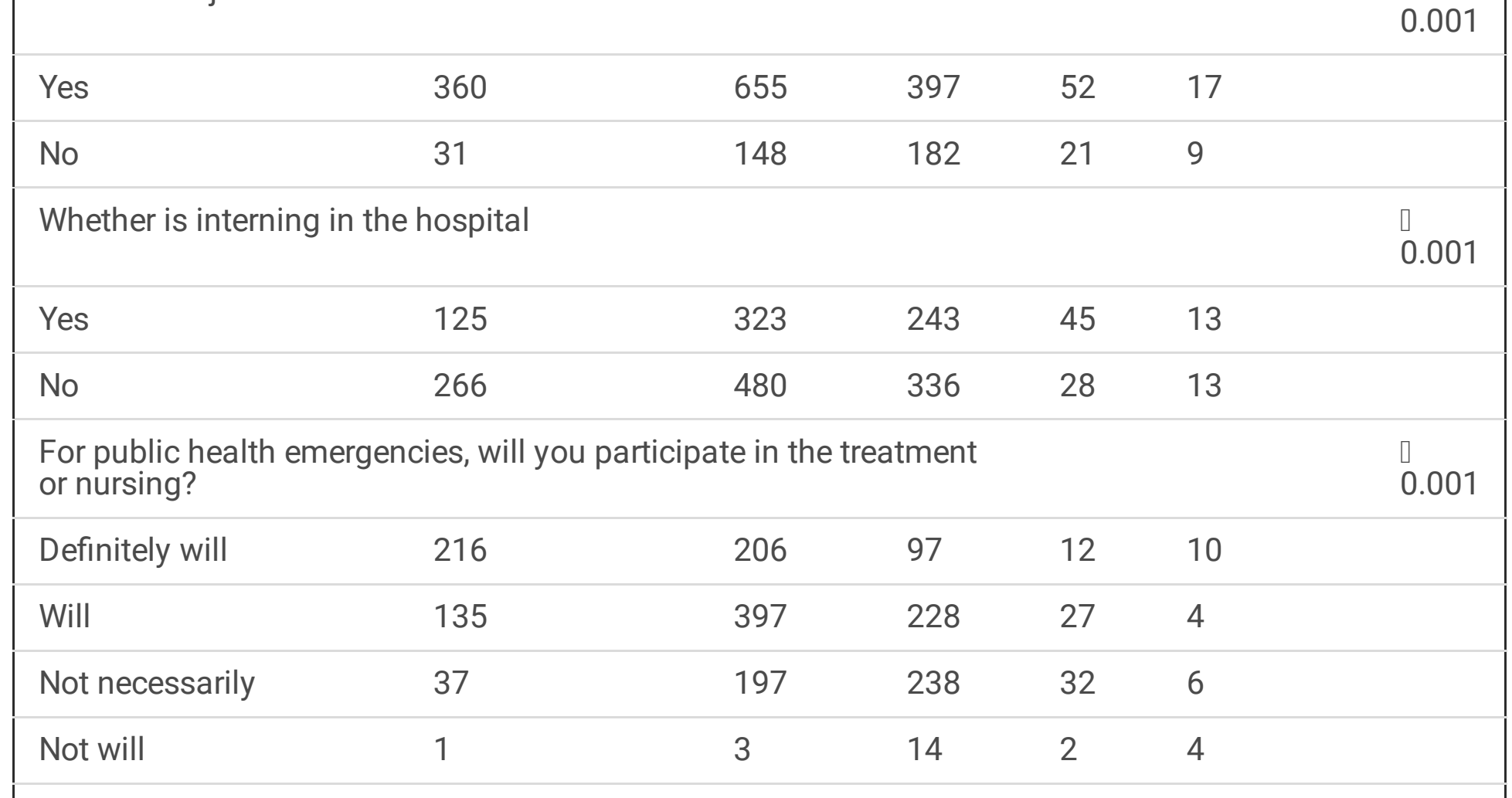




\begin{tabular}{|llllll|} 
Definitely not & 2 & 0 & 2 & 0 & 2 \\
\hline
\end{tabular}

Page 16/22 
Table 4 Factors associated with career choice regret after the COVID-19 epidemic in multinominal logistic regression $(\mathrm{n}=9322)$

\begin{tabular}{|c|c|c|c|c|c|c|c|}
\hline Career choice regret & & $\beta$ & SE & Wald & OR & $95 \% \mathrm{Cl}$ & $P$ \\
\hline \multirow{4}{*}{$\begin{array}{l}\text { With career choice } \\
\text { regret }\end{array}$} & Intercept & -5.578 & 0.549 & 103.156 & & & 0.000 \\
\hline & \multicolumn{7}{|c|}{$\begin{array}{l}\text { Total score of psychological } \\
\text { resilience }\end{array}$} \\
\hline & & -0.051 & 0.004 & 131.317 & 0.951 & $\begin{array}{l}0.943- \\
0.959\end{array}$ & 0.000 \\
\hline & Age & -0.010 & 0.007 & 2.119 & 0.990 & $\begin{array}{l}0.977- \\
1.004\end{array}$ & 0.146 \\
\hline
\end{tabular}

Total score of professional value after the covid-19 outbreak

$\begin{array}{llllll}0.440 & 0.017 & 652.894 & 1.552 & \begin{array}{l}1.501- \\ 1.605\end{array} & 0.000 \\ & & & & \end{array}$

Change of professional

value

$\left.\begin{array}{llllll}-0.151 & 0.022 & 48.630 & 0.860 & 0.824- & 0.000 \\ & & & & 0.897\end{array}\right]$

Identity

\begin{tabular}{|c|c|c|c|c|c|c|}
\hline Student & 0.503 & 0.163 & 9.477 & 1.654 & $\begin{array}{l}1.201- \\
2.278\end{array}$ & 0.002 \\
\hline Doctor & -0.297 & 0.160 & 3.466 & 0.743 & $\begin{array}{l}0.543- \\
1.016\end{array}$ & 0.063 \\
\hline Nurse & referenc & & & & & \\
\hline \multicolumn{7}{|l|}{ Gender } \\
\hline Female & -0.174 & 0.148 & 1.380 & 0.840 & $\begin{array}{l}0.629- \\
1.123\end{array}$ & 0.240 \\
\hline Male & referenc & & & & & \\
\hline \multicolumn{7}{|c|}{ The reason of career/major choice is personal ideal } \\
\hline No & 0.465 & 0.107 & 18.989 & 1.592 & $\begin{array}{l}1.291- \\
1.962\end{array}$ & 0.000 \\
\hline Yes & referenc & & & & & \\
\hline \multicolumn{7}{|c|}{ The reason of career/major choice is family will } \\
\hline No & 0.042 & 0.094 & 0.204 & 1.043 & $\begin{array}{l}0.868- \\
1.254\end{array}$ & 0.652 \\
\hline Yes & referer & & & & & \\
\hline
\end{tabular}


Whether experienced physical

violence

\begin{tabular}{|c|c|c|c|c|c|c|c|}
\hline & No & -0.395 & 0.117 & 11.449 & 0.673 & $\begin{array}{l}0.536- \\
0.847\end{array}$ & 0.001 \\
\hline & Yes & referenc & & & & & \\
\hline & \multicolumn{7}{|c|}{$\begin{array}{l}\text { Whether experienced verbal } \\
\text { violence }\end{array}$} \\
\hline & No & 0.121 & 0.121 & 1.001 & 1.129 & $\begin{array}{l}0.891- \\
1.430\end{array}$ & 0.317 \\
\hline & Yes & referenc & & & & & \\
\hline & \multicolumn{7}{|c|}{ Afraid of coronavirus degree } \\
\hline & Very afraid & 0.692 & 0.242 & 8.202 & 1.997 & $\begin{array}{l}1.244- \\
3.206\end{array}$ & 0.004 \\
\hline & Afraid & 0.385 & 0.202 & 3.639 & 1.470 & $\begin{array}{l}0.989- \\
2.183\end{array}$ & 0.056 \\
\hline & $\begin{array}{l}\text { General } \\
\text { afraid }\end{array}$ & 0.116 & 0.178 & 0.423 & 1.123 & $\begin{array}{l}0.792- \\
1.593\end{array}$ & 0.515 \\
\hline & Not afraid & -0.126 & 0.193 & 0.426 & 0.882 & $\begin{array}{l}0.604- \\
1.287\end{array}$ & 0.514 \\
\hline & $\begin{array}{l}\text { Not afraid at } \\
\text { all }\end{array}$ & referenc & & & & & \\
\hline \multirow[t]{10}{*}{ neutral } & Intercept & -1.866 & 0.298 & 39.148 & & & 0.000 \\
\hline & \multicolumn{7}{|c|}{$\begin{array}{l}\text { Total score of psychological } \\
\text { resilience }\end{array}$} \\
\hline & & -0.043 & 0.002 & 294.021 & 0.958 & $\begin{array}{l}0.953- \\
0.963\end{array}$ & 0.000 \\
\hline & Age & -0.016 & 0.004 & 18.175 & 0.984 & $\begin{array}{l}0.977- \\
0.991\end{array}$ & 0.000 \\
\hline & \multicolumn{7}{|c|}{ Total score of professional value after the COVID-19 outbreak } \\
\hline & & 0.252 & 0.010 & 687.117 & 1.287 & $\begin{array}{l}1.263- \\
1.311\end{array}$ & 0.000 \\
\hline & \multicolumn{7}{|c|}{ Change of professional value } \\
\hline & & -0.042 & 0.012 & 12.349 & 0.959 & $\begin{array}{l}0.937- \\
0.982\end{array}$ & 0.000 \\
\hline & \multicolumn{7}{|l|}{ Identity } \\
\hline & Student & 0.157 & 0.084 & 3.503 & 1.170 & $\begin{array}{l}0.993- \\
1.379\end{array}$ & 0.061 \\
\hline
\end{tabular}




\begin{tabular}{|c|c|c|c|c|c|c|}
\hline Doctor & 0.016 & 0.085 & 0.034 & 1.016 & $\begin{array}{l}0.860- \\
1.200\end{array}$ & 0.855 \\
\hline Nurse & referen & & & & & \\
\hline \multicolumn{7}{|l|}{ Gender } \\
\hline Female & 0.084 & 0.080 & 1.121 & 1.088 & $\begin{array}{l}0.931- \\
1.272\end{array}$ & 0.290 \\
\hline Male & referen & & & & & \\
\hline \multicolumn{7}{|c|}{ The reason of career/major choice is personal ideal } \\
\hline No & .601 & .055 & 120.181 & 1.823 & $\begin{array}{l}1.638- \\
2.030\end{array}$ & 0.000 \\
\hline Yes & referen & & & & & \\
\hline \multicolumn{7}{|c|}{ The reason of career/major choice is family will } \\
\hline No & 0.065 & 0.051 & 1.619 & 1.067 & $\begin{array}{l}0.966- \\
1.178\end{array}$ & 0.203 \\
\hline Yes & referen & & & & & \\
\hline \multicolumn{7}{|c|}{$\begin{array}{l}\text { Whether experienced physical } \\
\text { violence }\end{array}$} \\
\hline No & -0.006 & 0.072 & 0.007 & 0.994 & $\begin{array}{l}0.863- \\
1.145\end{array}$ & 0.934 \\
\hline Yes & referen & & & & & \\
\hline \multicolumn{7}{|c|}{$\begin{array}{l}\text { Whether experienced verbal } \\
\text { violence }\end{array}$} \\
\hline No & 0.249 & 0.060 & 17.086 & 1.283 & $\begin{array}{l}1.140- \\
1.444\end{array}$ & 0.000 \\
\hline Yes & referen & & & & & \\
\hline \multicolumn{7}{|c|}{ Afraid of coronavirus degree } \\
\hline Very afraid & 0.175 & 0.167 & 1.093 & 1.191 & $\begin{array}{l}0.858- \\
1.654\end{array}$ & 0.296 \\
\hline Afraid & 0.547 & 0.116 & 22.243 & 1.727 & $\begin{array}{l}1.376- \\
2.168\end{array}$ & 0.000 \\
\hline $\begin{array}{l}\text { General } \\
\text { afraid }\end{array}$ & 0.490 & 0.099 & 24.266 & 1.632 & $\begin{array}{l}1.343- \\
1.984\end{array}$ & 0.000 \\
\hline Not afraid & 0.223 & 0.105 & 4.495 & 1.250 & $\begin{array}{l}1.017- \\
1.536\end{array}$ & 0.034 \\
\hline $\begin{array}{l}\text { Not afraid a } \\
\text { all }\end{array}$ & refere & & & & & \\
\hline
\end{tabular}


\# The reference category is without career choice regret

Page 20/22 
Table 5 Factors associated with career choice regret after the COVID-19 epidemic in multinominal logistic regression among medical students $(n=1872)$

\begin{tabular}{|c|c|c|c|c|c|c|c|}
\hline \multicolumn{2}{|c|}{ Career choice regret } & \multirow{2}{*}{$\begin{array}{l}B \\
-2.372\end{array}$} & \multirow{2}{*}{$\begin{array}{l}\text { SE } \\
0.573\end{array}$} & \multirow{2}{*}{$\begin{array}{l}\text { Wald } \\
17.116\end{array}$} & \multirow[t]{2}{*}{ OR } & \multirow[t]{2}{*}{$95 \% \mathrm{Cl}$} & \multirow{2}{*}{$\begin{array}{l}P \\
0.000\end{array}$} \\
\hline \multirow{18}{*}{$\begin{array}{l}\text { With career } \\
\text { choice regret }\end{array}$} & Intercept & & & & & & \\
\hline & \multicolumn{7}{|l|}{ Major } \\
\hline & Nursing & 0.973 & 0.269 & 13.031 & 2.645 & $\begin{array}{l}1.56- \\
4.485\end{array}$ & 0.000 \\
\hline & Clinical Medicine & reference & & & & & \\
\hline & \multicolumn{7}{|c|}{ Work intention after graduation } \\
\hline & Tertiary hospital & -1.522 & 0.292 & 27.155 & 0.218 & $\begin{array}{l}0.123- \\
0.387\end{array}$ & 0.000 \\
\hline & Primary hospital & -0.62 & 0.45 & 1.899 & 0.538 & $\begin{array}{l}0.223- \\
1.299\end{array}$ & 0.168 \\
\hline & Others & reference & & & & & \\
\hline & \multicolumn{7}{|c|}{$\begin{array}{l}\text { Whether is interning in the } \\
\text { hospital }\end{array}$} \\
\hline & No & -0.211 & 0.27 & 0.615 & 0.809 & $\begin{array}{l}0.477- \\
1.373\end{array}$ & 0.433 \\
\hline & Yes & reference & & & & & \\
\hline & \multicolumn{7}{|c|}{ Whether major is the first choice } \\
\hline & No & 0.466 & 0.267 & 3.037 & 1.593 & $\begin{array}{l}0.944- \\
2.690\end{array}$ & 0.081 \\
\hline & Yes & reference & & & & & \\
\hline & \multicolumn{7}{|l|}{ Educational level } \\
\hline & $\begin{array}{l}\text { Below Bachelor } \\
\text { degree }\end{array}$ & 0.475 & 0.485 & 0.962 & 1.609 & $\begin{array}{l}0.622- \\
4.158\end{array}$ & 0.327 \\
\hline & Bachelor degree & 1.924 & 0.518 & 13.795 & 6.851 & $\begin{array}{l}2.481- \\
18.912\end{array}$ & 0.000 \\
\hline & $\begin{array}{l}\text { Master's degree or } \\
\text { doctorate }\end{array}$ & reference & & & & & \\
\hline \multirow[t]{4}{*}{ neutral } & Intercept & -0.825 & 0.297 & 7.728 & & & 0.005 \\
\hline & \multicolumn{7}{|l|}{ Major } \\
\hline & Nursing & 0.717 & 0.132 & 29.624 & 2.049 & $\begin{array}{l}1.583- \\
2.653\end{array}$ & 0.000 \\
\hline & Clinical Medicine & reference & & & & & \\
\hline
\end{tabular}


Work intention after graduation

$\begin{array}{lllllll}\text { Tertiary hospital } & -0.715 & 0.195 & 13.432 & 0.489 & 0.334- & 0.000 \\ & & & & & 0.717 & \\ \text { Primary hospital } & -0.685 & 0.288 & 5.655 & 0.504 & \begin{array}{l}0.287- \\ 0.886\end{array} & 0.017 \\ & & & & & & \\ \text { Others } & \text { reference } & & & & & \end{array}$

Whether is interning in the hospital

$\begin{array}{lllllll}\text { No } & 0.165 & 0.136 & 1.464 & 1.179 & 0.903- & 0.226 \\ & & & & 1.539 & \\ \text { Yes } & \text { reference } & & & & & \end{array}$

Whether major is the first choice

$\begin{array}{lllllll}\text { No } & 0.623 & 0.137 & 20.625 & 1.864 & \begin{array}{l}1.425- \\ 2.438\end{array} & 0.000\end{array}$

Yes

reference

Educational level

\begin{tabular}{lcccccc|}
$\begin{array}{l}\text { Below Bachelor } \\
\text { degree }\end{array}$ & 0.145 & 0.225 & 0.419 & 1.157 & $\begin{array}{l}0.744- \\
1.797\end{array}$ & 0.518 \\
\hline Bachelor degree & 0.755 & 0.263 & 8.244 & 2.128 & $\begin{array}{l}1.271- \\
3.563\end{array}$ & 0.004 \\
& & & & & &
\end{tabular}

Master's degree or reference doctorate

\# The reference category is without career choice regret 